\title{
Government Regulation of Small and Medium Entrepreneurship under the Influence of Value-Time Benchmarks
}

\author{
Akhmetshin R.M.a \\ Shafigullina A.V. ${ }^{b}$ \\ ${ }^{a b}$ Kazan Federal University, Institute of Management, Economics and Finance, Kazan, 420008, Russia
}

\section{Doi:10.5901/mjss.2015.v6n1s3p151}

\begin{abstract}
The article describes the role of regional infrastructure provision in small and medium entrepreneurship development in the Republic of Tatarstan. It covers and analyses efforts of republic's government in small businesses support. Statistical data reflecting positive dynamics of measures implemented is given.
\end{abstract}

Keywords: small and medium entrepreneurship, infrastructure, government support.

\section{Introduction}

Government regulation of socio-economic development of Russian Federation aims to switch to innovative progressive dynamics. At the present stage of economic development one of the priority directions of this regulation is to create an infrastructure for entrepreneurial activity growth. In current institutional conditions existing barriers to market entry in most spheres of economic activity are prohibitively high for small and medium businesses. It should be noted that, according to the Strategy for development of the Russian Federation for the period until the year 2020, namely these measures have to become the background for positive forward dynamics provision, what makes the research priority-driven. As practice shows, the main reason for high level of barriers mentioned above is lack of infrastructure development (transport, innovative, logistical, financial and managerial).[6] Its influence is strengthened by economic space polarization and results in gradual business recession at early stages of business development. Thus, we witness gradual decline in share of small entrepreneurs in total number of business units. Therefore, at the current moment the priority aim of business activity government regulation is to build an infrastructure system that would meet small businesses' needs and consider spatial polarization as well as national socio-economic system imbalances.

\section{Theory}

While building and introducing complex infrastructure for entrepreneurs and supporting its operation and development it is necessary to take into account the fact that more than $80 \%$ of new jobs are added by small businesses.[3] At the same time entrepreneurs of these type run into many difficulties while getting access to infrastructure objects due to funds raising problems in an initial stage of development. Consequently government regulation of infrastructure provision for entrepreneurs has to be structured with due regard for small enterprises needs that would provide equal conditions for breaking through market entry barriers. Russia's entry to the WTO has increased the need of creating conditions for small and medium-sized enterprises effective development because of market competition growth and as consequence of all that decrease in small businesses competitiveness over extra pressure of market barriers not in the last instance affected by relatively low level of infrastructure development. Government interest in that issue is based on tax revenues accumulated by small businesses in local authority budgets facing considerable imbalance problems, and also driven by the need to smooth spatial economic polarization resulting largely from small and medium-sized enterprises development trends.[9] As best world practices in creating favorable conditions for small enterprises show that the most effective longterm regulation instruments are investments in infrastructure since the level of its development is a key incentive for business activity growth at early stages of company's life cycle.

This fact has caused the need to study the possibilities and priority directions for government regulation of resources supply, necessity to develop effective tools and mechanisms for entrepreneurial infrastructure government regulation system on different levels of managerial hierarchy, which formed the bases for topicality of the research, its 
theoretical and practical significance at the present stage of Russian economic development.

The article gives an analysis of theoretical approaches to entrepreneurship development, showing that in order to provide effective government regulation of the sphere the Entrepreneurial Canvas Model designed at the University of Maryland should be used as the appropriate basic business model. The model mentioned above clearly differentiates external and internal environment of small enterprises, what has determined the choice of the model as methodological platform of the dissertation research. According to the approach the model canvas puts different types of infrastructure into the boxes in the canvas, where each box specifies what kind of infrastructure provision corresponds with certain element of small business development (see Picture 1).[4]

\begin{tabular}{|c|c|c|c|c|c|}
\hline \multicolumn{2}{|c|}{$\begin{array}{l}\text { Entrepreneurial thinking } \\
\text { social infrastructure }\end{array}$} & \multicolumn{2}{|c|}{$\begin{array}{l}\text { Entrepreneur motivation } \\
\text { innovative infrastructure }\end{array}$} & \multicolumn{2}{|c|}{$\begin{array}{l}\text { Entrepreneur behaviour } \\
\text { managerial (administrative) } \\
\text { infrastructure } \\
\text { social infrastructure }\end{array}$} \\
\hline \multirow[t]{3}{*}{$\begin{array}{c}\begin{array}{c}\text { External } \\
\text { environment of }\end{array} \\
\text { business } \\
\text { engineering } \\
\text { infrastructure } \\
\text { financial } \\
\text { infrastructure }\end{array}$} & \multicolumn{2}{|c|}{$\begin{array}{l}\text { Industry features } \\
\text { information infrastructure }\end{array}$} & \multicolumn{2}{|c|}{$\begin{array}{c}\text { Competition } \\
\text { managerial infrastructure } \\
\text { logistic infrastructure }\end{array}$} & $\begin{array}{c}\text { Entrepreneurial } \\
\text { opportunity } \\
\text { information } \\
\text { infrastructure } \\
\text { managerial } \\
\text { infrastructure }\end{array}$ \\
\hline & \multicolumn{2}{|c|}{$\frac{\text { Industry's current position }}{\text { production infrastructure }}$} & \multicolumn{2}{|c|}{$\begin{array}{l}\text { Creating customer value } \\
\text { production infrastructure }\end{array}$} & $\begin{array}{l}\text { innovative } \\
\text { infrastructure }\end{array}$ \\
\hline & \multicolumn{2}{|c|}{ transport infrastructure } & \multicolumn{2}{|c|}{ innovative infrastructure } & \\
\hline
\end{tabular}

Picture 1. Typology of small and medium-sized entrepreneurship infrastructure types in the context of OEC elements

\section{Results}

Entrepreneurial community of the Republic of Tatarstan came to conclusion that favourable business environment is one of the main conditions for the economy growth. Need to mention, that the government of the Republic of Tatarstan is responsible for building sustainable entrepreneurial ecosystem. Efforts implemented in that direction could be presented as follows: government support of small and medium-sized enterprises, building a dialog with business community, incitement of youth interest in entrepreneurship, creating a platform for attracting investments (including foreign investments), innovative businesses development.[7]

One of the most interesting ways of small and medium enterprises support in the Republic of Tatarstan is "Youth Entrepreneurship in the Republic of Tatarstan for the period 2012-2016" long-term program implementation. The program aims to create conditions for youth involvement in socio-economic development if the Republic of Tatarstan. [5] The main objectives of the educational program are:

- the development of an information supply system for young people in entrepreneurial area;

- $\quad$ the formation of a positive image of the business;

- the development and implementation of educational programs for enterprising young people;

- support aspiring young entrepreneurs and business promotion of youth entrepreneurship projects.

While accomplishing abovementioned objectives the following measures were implemented: together with municipal institutions some steps in youth entrepreneurship development were made; youth inquiry consulting and information and consulting services supply practices were introduced; republic remote business education programs were developed and implemented; business trainers working with businesslike young people were prepared in municipal institutions of the Republic of Tatarstan.[8] Along with these measures annual conference for enterprising young people "Step forward" were held, where different issues including young people business potential development and their contribution to socio-economic development of the Republic of Tatarstan were discussed.

The idea of creating business camps for young entrepreneurs was implemented in municipal institutions of the Republic of Tatarstan, managerial and business trainings, managerial competitions, championship developing entrepreneurial competences among managers, and other events were held. Local and republican school business 
companies meetings were organised, the process of creating and introducing an educational course named "Entrepreneurship basics for school children" in school program is in work.

\section{Conclusions}

Summarizing interim results of "Youth Entrepreneurship in the Republic of Tatarstan for the period 2012-2016" long-term program implementation we can identify the following tendencies related to businesslike young people. The basic tendency is particular interest in entrepreneurial business in services sector. While implementation of measures mentioned within the Program, enterprising young people were offered to write a plan for their "own business", further assessment of these business plans showed that overwhelming majority of projects were related to services sector - hotel business, public catering business (cafes, restaurants), and beauty salons of different types (stationary, mobile), etc.[1] The Government of the Republic of Tatarstan assumed, that such kind of measures would stimulate entrepreneurial activity in the region, and that was proven by statistical data given in Table 1.

Table 1. The main trends in entrepreneurship development in the Republic of Tatarstan

\begin{tabular}{|c|c|c|c|c|c|}
\hline Index & 2010 (fact) & 2011 (fact) & 2012 (fact) & 2013 (fact) & 2014 (plan) \\
\hline \multicolumn{6}{|l|}{ Number of economically active business units: } \\
\hline Small businesses, thousands of units & 42,3 & 46,5 & 47,9 & 49,3 & 51,0 \\
\hline Medium enterprises, units & 759,0 & 559,0 & 521,0 & 510,0 & 500,0 \\
\hline Sole proprietorship, thousands of units & 128,3 & 116,8 & 111,0 & 106,1 & 100,0 \\
\hline $\begin{array}{l}\text { Small and medium-sized enterprises share in growth } \\
\text { regional product, \% }\end{array}$ & 24,5 & 25,3 & 25,2 & 27,0 & 28,0 \\
\hline $\begin{array}{l}\text { Number of employees working at small and medium-sized } \\
\text { enterprises, thousands of people }\end{array}$ & 379,1 & 390,3 & 392,7 & 394,6 & 396,0 \\
\hline $\begin{array}{l}\text { Share of people occupied in small and medium businesses } \\
\text { in total number of working people in the republic, } \%\end{array}$ & 27,8 & 28,6 & 28,8 & 29,5 & 30,5 \\
\hline $\begin{array}{l}\text { Turnover of small and medium businesses and sole } \\
\text { proprietors, bln rubles }\end{array}$ & 851,7 & 1031,7 & 1062,2 & 1089,3 & 1150,0 \\
\hline $\begin{array}{l}\text { Share of small and medium businesses investments in } \\
\text { total volume of investments in the republic, } \%\end{array}$ & 7,0 & 10,0 & 11,8 & 12,0 & 12,5 \\
\hline
\end{tabular}

Main highlights analysis shows a positive dynamics in small and medium-sized entrepreneurship development in the Republic of Tatarstan, what is undoubtedly a result of small and medium enterprises support within the Republican program of small and medium entrepreneurship development in the Republic of Tatarstan for the period 2011-2016.

From 2012 to 2014 within the program implementation 3,5 bln rubles were spent on entrepreneurship development in the Republic of Tatarstan, including 1,4 bln rubles from the budget of the Republic of Tatarstan and more than 2 bln rubles шт form of federal grant.

\section{References}

Antonchenko N.G., Kalenskaya N.V. Developing a Methodology for Assessing the Efficacy of Managerial Decisions in Entrepreneurial Establishments (2014) Life Science Journal 11.

Huning, S., Naumann, M., Bens, O., Hüttl, R.F. Transformations of modern infrastructure planning in rural regions: The case of water infrastructures in Brandenburg, Germany // European Planning Studies19 (8) , 2011. pp. 1499-1516

Kalenskaya N.V The Model of Infrastructural Support of Regional Innovative Development (2014) Mediterranean Journal of Social Sciences 18, pp. 317-323.

Kalenskaya N.V., Akhmetshin R.M., Grigoryeva L.L. The Development of State Regulation in Small Entrepreneurship Infrastructure Provision (2014) Mediterranean Journal of Social Sciences 18, pp. 27-33.

Kalenskaya N.V, Shafigullina A.V. The Invariance as a Feature of Business Systems' Infrastructural Innovative Development (2014) Mediterranean Journal of Social Sciences 18, pp. 241-247.

Novikova E., Beloborodova A. An Assessment of the Efficiency of the Information System of Design-and-survey Organizations Based on the Analysis of the Information Capacity of Projects Implemented (2014) World Applied Sciences Journal 29(1), pp. 20-25.

Palyakin R. B., Tarkaeva N. A. The Relationship of Entrepreneurial Activity and the Level of Institutional and Market-Based Infrastructure of Business (2014) Mediterranean Journal of Social Sciences №18 (v5), pp. 305-311.

Valeeva J.S., Sharafutdinova N.S., Kulkova V.Y., Quality management system's role in operation of retail trade networks (2014) Life Science Journal 11(5), pp. 555-558. 
Kramin, M. V., Safiullin, L. N., Kramin, T. V., \& Timiryasova, A. V. (2014). Drivers of economic growth and investment attractiveness of Russian regions. Life Science Journal, 11(6s).

Kramin, T. V., Ismagilova, G. N., \& Kramin, M. V. (2014). Assessment of Effect of Large Investment Projects on Development of Investment Potential of Regions of Russia as Exemplified by Universiade 2013 in Kazan1. Mediterranean Journal of Social Sciences, 5(18), 255.

Kramin, T. V., Safiullin, L. N., \& Timiryasova, A. V. (2014). Defining Priorities of Management of Investment Attractiveness of the Region and their Consideration in the Framework of Implementing Large Sports Events1. Mediterranean Journal of Social Sciences, 5(18), 275.

Wyrwich, M. Regional Entrepreneurial Heritage in a Socialist and a Postsocialist Economy // Economic Geography 88 (4), 2012. pp. 423445

Zheleva S.E., Saktoev V.E., Tsyreneva E.D., Industrial aspects of socio-economic systems' sustainable development (2005) VSGTU press, p.156.

Ablaev I.M., Khovanskaya E.S. Essence and Economical Substance of Innovative Cluster in Territorially Localized Business System// Mediterranean Journal of Social Sciences.- Vol.5, No12, (2014)-pp.159 - 162.

Varlamova J.A., Larionova N.I. Economic behavior of households: cross-country comparison. Life Science Journal 2014; 11(6s): 409413.

I.Sh. Khasanov, Three-sector structure of the national economy of Russia // Asian Social Science, Volume 10, 2014, Pages 217-224.

Vakhitova T.M., Gadelshina L.A. Directions of the region transport infrastructure development in the context of its competitiveness // Mediterranean Journal of Social Sciences vol. 5 № 24, November 2014, pp. 313-316. 